\title{
Skin Kites
}

\section{Rafael S.W}

THERE WAS, LIVING down near the end of the street, a monster. He walked with the soft footfall tread of scabs flaking away under fingers. He wore a green coat with three sleeves and a pair of socks, which he changed every Wednesday. On warm days he would sit close (but not too close) to the school and read the same newspaper and have irritable bowels from all the small pieces of bone that made their slow, slow progress through his intestines. He drank tea not with milk or sugar, but with a slice of lemon. So it went, that through winter he had a thermos that smelled of clothing freshener and a newspaper that didn't change except for slowly yellowing in his hands.

This monster had a home, where he sat in semi-darkness (for he felt light like the touch of red, raw passionless kisses). He sat in semidarkness and experimented with how close he would put his fingers to the mawing jaws of the garbage disposal before he drew back. Night taught him the fragility of fingers. The way those little twitchers would tingle the moment before they were kissed by the metal lips. The way they would tingle after, in their bloodbath of iodine and tap water. Fingers were fragile. And he only had twelve left. His evenings were metal eating flesh, or flesh tasting of metal. There was very little besides this, this and his hobbies. He was an artist. And he kept photos of them, all his little children. Developed in the darkroom where the soft fleshy photos grew; like mushrooms he stroked their soft white underbellies.

Alotofhisdayswerefilled with thestaleblood-tang of boredom. Routine stuck in his throat and there were times when he had to self-administer a Heimlich manoeuvre of excitement or risk becoming dust. Some days just passed slowly. When he yawned, his mouth was filled with baby teeth from where he had beaten the tooth fairy to the place under the pillows. On these days he crept a little closer to the schoolyard and let his body solidify in the heat. His newspaper crumpled and crinkled on his lap. 
His antennae quivered for recess when the children ran around with their flesh flying everywhere. Brightly, tethered only by their clothing and rules, they were skin kites and he longed to hold them between his hands, feel them trembling for sky.

There were times when dark cars drove between him and the school. Policemen lived in these, watching him, watching for the black-dangers any of which could befall a child walking his way home from school. The monster made sure to shrink when he saw the cars, sometimes uniformed, sometimes just dark. They watched him though; he could see them, whispering their secrets into the transmitters. His breath was rind in his throat each time he glimpsed them. They were prowling.

Then, on a sudden Tuesday, none of the children came out for recess. The monster didn't know what had happened. He heard the bell with the same knee bone twitch as usual. The clouds had leaked away since the morning and so there was no reason for them to be inside. But they were, they were, with their heads bobbling away inside the classrooms, their faces too far away to be more than some sort of sea-life viewed from a distance. They wavered all through the tight half hour, and then settled down again. But indoors. It was a torture. All he wanted was them closer, but they were covered by fences. Hidden by chalk and glass. He felt as if his body had become windows from watching. His organs moved around inside him, visible to the outside world. He walked home, squelching.

The next day there was a special assembly. He crept still closer for this, so as to find out if there would be a recess today. The assemblyman spoke in slow sad words, as if someone had died. He couldn't really hear the words though, the floorboards muffled a lot of the sound. The space under the hall was dank and stones crunkled against his spine where they were soon absorbed into his epidermis. He turned his head to the side so that he could hear better. Basketballs the size of rats squatted in his vision and a three-week-old sandwich gnawed at his feet. The assemblyman spoke words. People left, scraping their chairs back in sadness. The monster had to lie there until it was cold and the moon flicked her toenails at him, so he could get home without being seen. 
He spent the next few days alone with his children. He stroked them under the chin and felt them glossy under his touch. But it wasn't like the real thing.

As soon as he crawled to the school they got him. He wasn't surprised when the police came for him, their truncheons knickknocking against the skulls they had round their belts. He didn't even hear them, creeping up in their silken carapaces, polished black eyeballs gleaming.

Keshel keshel keshel. Their batons on his teeth. The ragged yellow newspaper crunching under boots. And his mouth, all through it going keshel keshel keshel.

They thought it was he that had done it. And how could he tell them otherwise? Already he was spitting truths, saliva flecked, onto the pavement. The children were in period two, and not many would see, and he was glad of this. The police batons were asking him if he had done it. And he was trying to tell them, no. But his guts were pouring from his hands, which he held out, all bloodied from the sinkeater, and they took this as further evidence. As they broke his skull under their boots all he could think of was goose bumps, small-headed children with eyes that didn't quite yet seem attached to their faces, mushrooms. 